\title{
Linear Triphosphines as Ligands for Metal Complexes Immobilization in Ionic Liquids: Palladium-Catalyzed Methoxylation of Alkynes
}

\author{
Lydie Harmand, Samer Saleh, Jacques Andrieu*, Hélène Cattey, Michel Picquet and Jean-Cyrille \\ Hierso
}

Institut de Chimie Moléculaire de l'Université de Bourgogne (ICMUB)-UMR 5260 CNRS 9, av. Alain Savary 21078 DIJON, France

\begin{abstract}
Several novel palladium triphosphine complexes have been synthesized and tested as recyclable catalysts for the methoxylation of alkynes into acetals in ionic liquids. A complete conversion of phenylacetylene was achieved with only $0.2 \%$ of $[\mathrm{Pd}($ Triphos $) \mathrm{NCMe}]\left[\left(\mathrm{PF}_{6}\right)_{2}\right]$ in a methanol/[BMIM] $\left[\mathrm{BF}_{4}\right]$ mixture. We discovered that the addition of an ionic liquid to methanol allowed not only to increase the activity of the palladium catalyst but also to provide a recyclable catalyst which can be reused several times with a weaker drop of activity. To complete these catalytic studies, we describe the synthesis of the first poor $\sigma$-electron-donating/strong $\pi$-electron-acceptor linear Triphosphine which, after palladium coordination, led to a better selectivity compared to its Triphos analogue. The performances of recovered ionic liquid reaction mixtures show for the first time that P-tridentate ligands efficiently immobilize palladium catalysts and lead to selective catalytic systems benign for environment.
\end{abstract}

Keywords: Polyphosphines, electron-poor ligands, palladium, ionic liquids, recyclable catalyst.

\section{INTRODUCTION}

The construction of $\mathrm{C}-\mathrm{O}$ bonds by addition of alcohols to a $\mathrm{C}-\mathrm{C}$ triple bond represents today one of the most useful methods to functionalize internal and terminal alkynes. As a consequence, a variety of catalysts have been studied for this reaction which leads essentially to acetals.

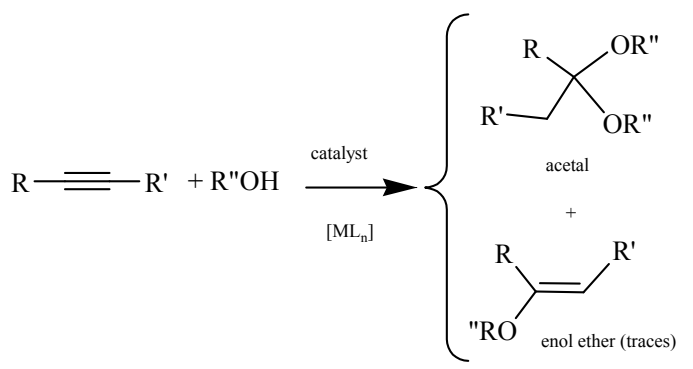

Equation. (1). Addition of alcohols to alkynes.

For instance, $\operatorname{In}(\mathrm{III}), \mathrm{Zr}(\mathrm{IV}), \mathrm{Au}(\mathrm{I})$ and $\operatorname{Ir}(\mathrm{I})$ complexes were found to be active in selective formation of spiroacetals from alkynes, [1-3] which are motifs or substructures of numerous fragrances, [4-6] insect pheromones, [7] polyketides natural products, $[8,9]$ anesthetic drugs, [10] or biodegradable synthetic biomaterials. [11] Other reports indicate that the addition of methanol to non-activated alkynes can be promoted by rhodium, [12] platinum dihalides with sodium sulfate as co-catalyst, [13] phosphite-iridium complexes

*Address correspondence to this author at the Institut de Chimie Molé culaire de l'Université de Bourgogne (ICMUB) - UMR 5260 CNRS 9, av. Alain Savary 21078 DIJON, France; Tel: 003338039 6106;

Fax: 003338039 3682; E-mail: Jacques.Andrieu@u-bourgogne.fr eventually combined with a Lewis acid, [14,15] or a phosphine-cationic gold complex in situ generated in the presence of a strong Brønsted acid. [16] We have focused our investigation on the activity of palladium complexes since, in addition to copper complexes, [17] they specifically catalyze one-pot three-component reactions using alkynes, alcohols and aryl iodides as starting material. [18] The control of metal-phosphine leaching in the mobile phase still remains in all cases a major problem in the alkyne methoxylation catalysis. To tackle this issue, two approaches can then be envisaged: i) either the use of imidazolium monophosphine salts as immobilizing ligands, similarly to studies devoted to palladium alkynylation, platinum hydrogenation and rhodium hydroformylation catalysis in ionic liquids, [19, 20] or ii) the use of flexible polyphosphine ligands to stabilize ionic palladium complexes. [21] We opted for the use of polyphosphine ligands with regards to their robustness, and their good metal-immobilizing abilities by coordination to cationic complexes in ionic liquids. They are also susceptible to functionalization by a dangling imidazolium (or imidazolidinium) ionic fragment to enhance their anchoring capacity into highly polar media. [22,23]

In several cases, the replacement of triphenylphosphine ligands by trifurylphosphine has led to enhanced activity in metal catalysis. For instance, better performances were found in palladium-catalysed aryl alkynylation, in platinumcatalysed hydrogenation of chloronitrobenzene, [19] for Negishi cross-coupling, [24] and for rhodium catalyzed reactions. [25] We thus postulated that better catalytic performances may also be achieved from an increased Lewis acidic character of the metal centre through the introduction of electron-withdrawing groups in a tridentate phosphine 
ligand. In the case of alkynes methoxylation, the nucleophilic addition of methanol to the palladium-coordinated alkyne may then be efficiently promoted. We focused our synthetic efforts on the preparation of the first example of a poor $\sigma$-electron-donating linear triphosphine. The resulting ligands and their corresponding palladium-complexes were fully characterized and tested in the methoxylation of phenylacetylene and 1-octyne in organic or ionic solvents. Recovery and recycling runs were successfully conducted in the ionic liquid [BMIM] $\left[\mathrm{BF}_{4}\right]$.

\section{RESULTS AND DISCUSSION}

\section{A. Synthesis of Triphosfurane Ligand}

Our synthetic approach to get the modified triphosphine 2, named Triphosfurane, was based on the reaction of $\mathrm{Fu}_{2} \mathrm{PBr}$ [bis(5-methyl-2-furyl)bromophosphine], prepared according to the literature, [26,27] with vinyl magnesium bromide via a Grignard reaction, similarly to its analogous vinyl diphenylphosphine $\mathrm{Ph}_{2} \mathrm{PCH}=\mathrm{CH}_{2}$ [28] and followed by a radical-induced double hydrophosphorylation of phenylphosphine (See Scheme 1).

Under such conditions, the vinyl difurylphosphine 1 was obtained selectively as shown by the presence in the ${ }^{31} \mathrm{P}$ NMR spectrum of a single signal at $-57 \mathrm{ppm}$. However, when the conditions described for the preparation of Triphosline [23] were applied to this vinyl difurylphosphine 1 in the presence of phenylphosphine and AIBN, several signals were observed in the corresponding spectrum (Fig $\mathbf{1}$ ).
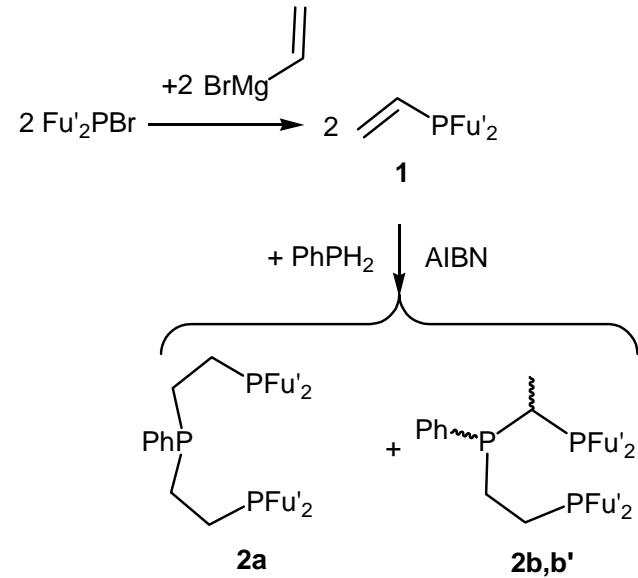

Triphosfuranes

\begin{tabular}{l|c|c} 
at $105{ }^{\circ} \mathrm{C}$ & $\mathbf{( 2 a )} 54 \%$ & $\mathbf{( 2 b , b ^ { \prime } )} 46 \%$ \\
\hline $\begin{array}{l}\text { under Hg lamp } \\
\text { without cooling }\end{array}$ & $\mathbf{( 2 a ) 7 5 \%}$ & $\mathbf{( 2 b , b ^ { \prime } )} 25 \%$ \\
\hline $\begin{array}{l}\text { under Hg lamp } \\
\text { cooled at 5 }{ }^{\circ} \mathrm{C}\end{array}$ & $\mathbf{( 2 a )} 90 \%$ & $\mathbf{( 2 b , b ^ { \prime } )} 10 \%$
\end{tabular}

Scheme. (1).

The signals which appeared as a doublet and a triplet at -59 and at $-17 \mathrm{ppm}$ with a typical $[22,23]{ }^{3} J_{\mathrm{PP}}$ coupling constant of $32 \mathrm{~Hz}$ were assigned to the expected Triphosfurane ligand 2a $\left[\mathrm{PhP}\left(\mathrm{CH}_{2} \mathrm{CH}_{2} \mathrm{PFu}_{2}\right)_{2}\right]$ respectively for the external and internal phosphorus atoms. The other signals appearing as a couple of doublet at -35 , a triplet at -37 and a

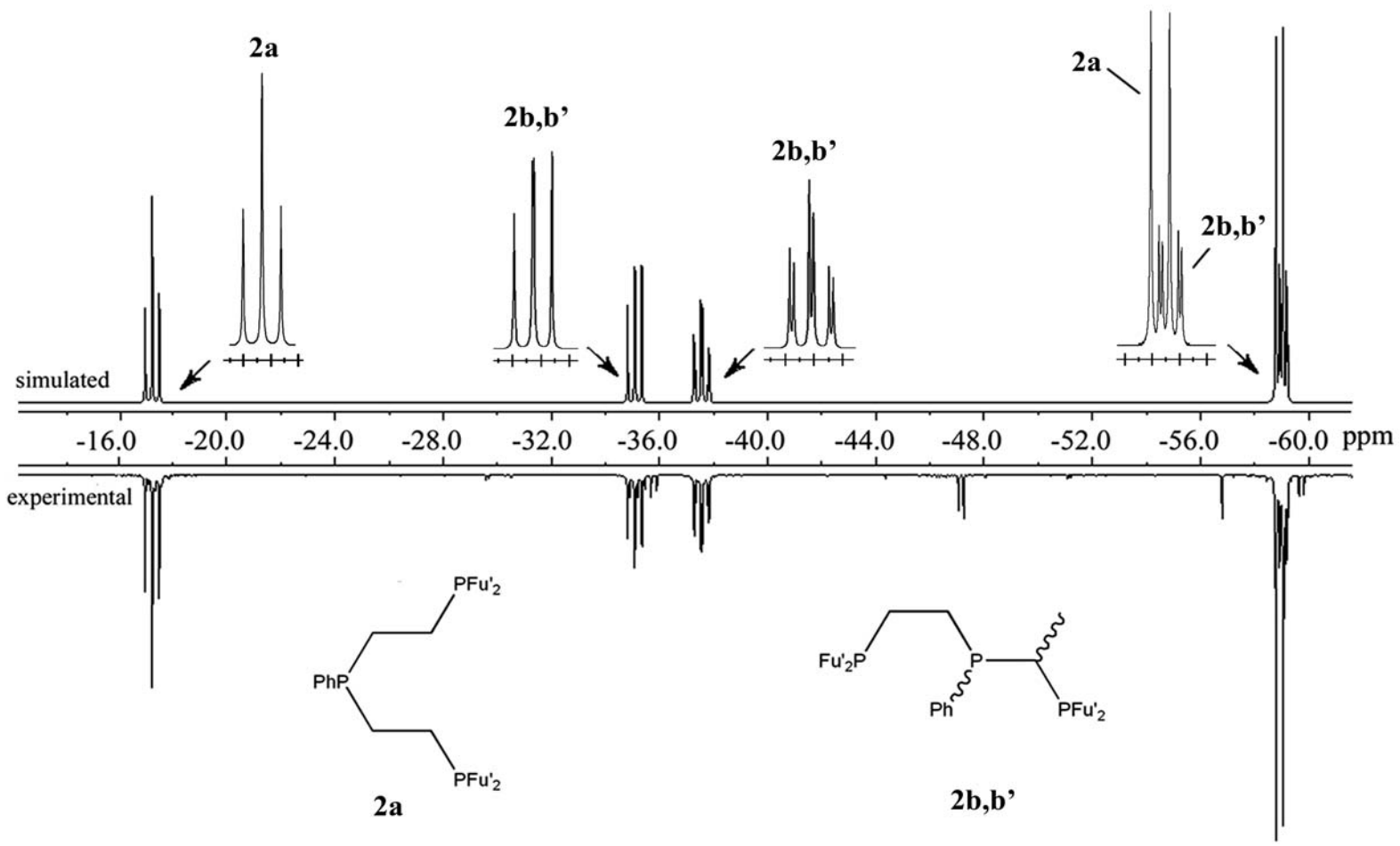

Fig. (1). Simulated and experimental ${ }^{31} \mathrm{P}\left\{{ }^{1} \mathrm{H}\right\}$ NMR spectra of Triphosfuranes 2. 


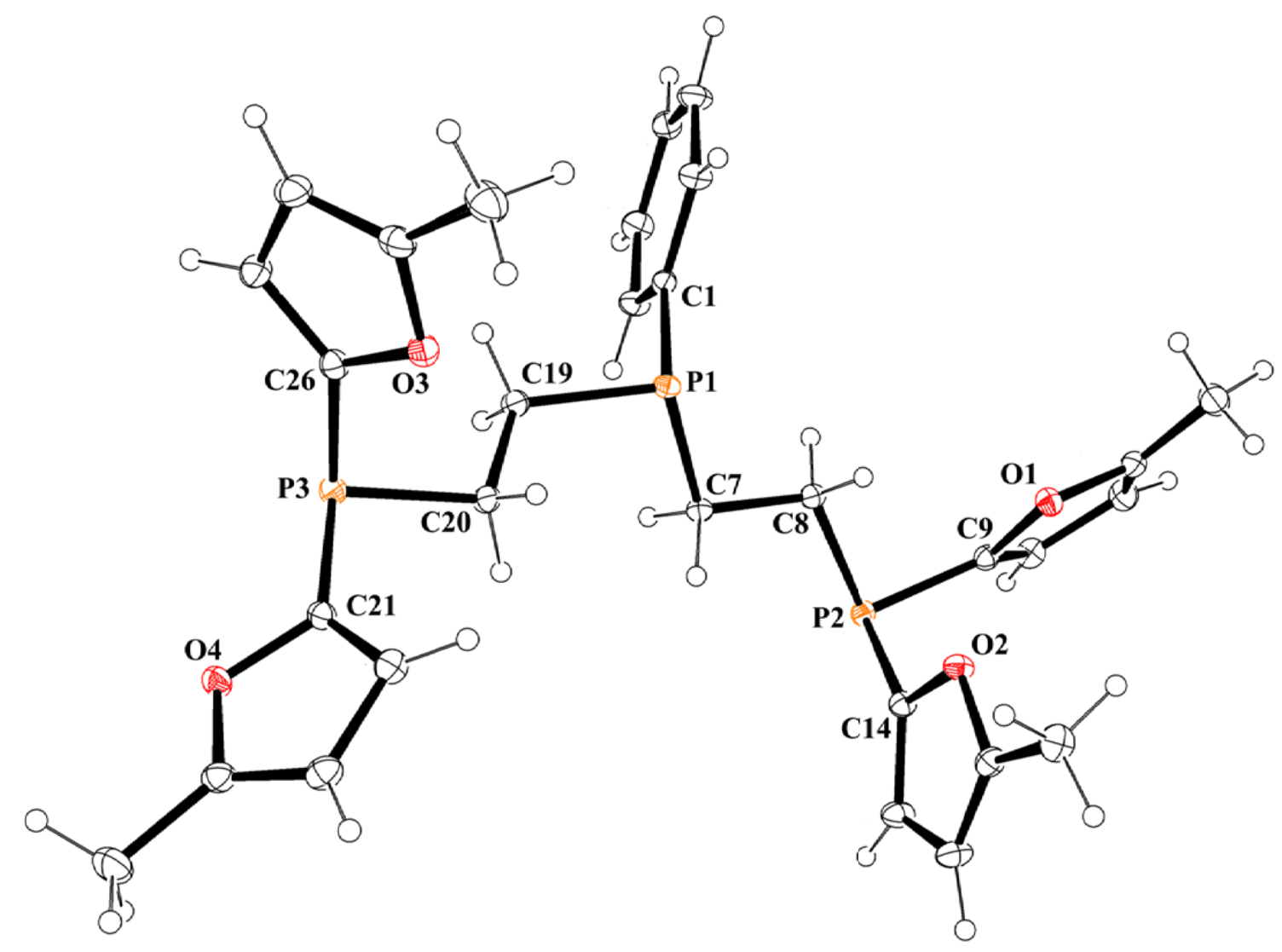

Fig. (2). ORTEP view of Triphosfurane 2a.

doublet at $-59 \mathrm{ppm}$ with same intensities were assigned to an AMX pattern corresponding to the diasteroisomers $\left[\mathrm{Fu}_{2}^{\prime} \mathrm{PCH}_{2} \mathrm{CH}_{2} \mathrm{PPhCH}\left(\mathrm{CH}_{3}\right) \mathrm{PFu}_{2}\right] \mathbf{2 b}$ and b', with an expected $\mathbf{2 b}$ : 2b' ratio equal to one, see Fig. (1). The $2 \mathbf{a}$ and 2b,b' isomers were present in similar amount (Scheme 1). The structure proposed for the Triphosfurane $\mathbf{2 b} \mathbf{b}, \mathbf{b}$ ' was further proved by an additional electrospray analysis of the mixture which shows only one molecular peak for both Triphosfurane ligands 2 (see experimental section for details). It is noteworthy that this kind of isomer $\mathbf{2 b}, \mathbf{b}$ ' was never observed with the phenyl analogue. To explain the formation of this compound, we suggest that during the first addition reaction of vinyldifurylphosphine to the phenylphosphine radical $[\mathrm{PhPH}]^{\bullet}$ the presence of two electronwithdrawing furyl groups either renders the internal vinyl carbon more reactive than the external one, or destabilizes the secondary adduct radical $\left[\mathrm{Fu}_{2}^{\prime} \mathrm{PCH}{ }^{\bullet}-\mathrm{CH}_{2} \mathrm{PHPh}\right]$. The regioselectivity of the second addition of vinyldifurylphosphine then follows a classical anti-Markovnikov addition which decreases the steric effects generated by the different bulky phosphorus fragments.

This poor regioselectivity during the formation of the expected Triphosfurane 2a was improved by changing the reaction conditions. Consequently, $t \mathrm{BuOK}$ was tested as catalyst instead of AIBN, but the $2 \mathbf{a}: \mathbf{2 b}$, b' ratio remained unchanged. A better regioselectivity was observed when a photochemical irradiation was used to activate AIBN instead of heating. Regioselectivity became excellent by cooling of the reaction medium to $5{ }^{\circ} \mathrm{C}$. The undesirable kinetic pro- ducts Triphosfuranes $\mathbf{2 b}, \mathbf{b}$ ' were then found to be less than $10 \%$. A further crystallization allowed isolating pure Triphosfurane 2a as colorless crystals suitable for X-ray structure analysis, as displayed in Fig. (2).

In the solid state molecular structure the backbone which incorporates the three phosphorus atoms and the methylene groups forms a semicircle arch, with the lone electron-pairs of each phosphorus atom alternatively pointing in opposite direction. The oxygen atoms from furyl fragments are found to be either on synperiplanar (O1 and O2, Fig. 2) or antiperiplanar position (O3 and O4, Fig. 2). Such arrangement induces a different chemical environment for methylene groups which is not detected at room temperature by ${ }^{1} \mathrm{H}$ and ${ }^{13} \mathrm{C}$ solution NMR spectroscopy in $\mathrm{CDCl}_{3}$, certainly due to free rotation of the $\mathrm{P}-\mathrm{CH}_{2}$ bonds. This contrasts with the different chemical shifts observed for the methylene groups upon palladium coordination. The sum of $\mathrm{P}-\mathrm{C}$ angles being identical for $\mathrm{PFu}_{2}^{\prime} \mathrm{CH}_{2}$ and $\mathrm{PhP}\left(\mathrm{CH}_{2}\right)_{2}$ moieties means that the different phosphorus groups adopt the same pyramidal geometry (see Table $\mathbf{1}$ and 2). It is also interesting to compare the different $\mathrm{P}-\mathrm{C}$ bond lengths. Indeed, they decrease continuously from $\mathrm{P}-\mathrm{C}_{\text {alkyl }}$ (1.853 to $1.847 \AA$ ), $\mathrm{P}-\mathrm{C}_{\mathrm{Ph}}(1.835$ $\AA$ ) to $\mathrm{P}-\mathrm{C}_{\mathrm{Fu}}$ bonds (1.811 to $1.804 \AA$ ) exactly like in the ethylbis(2-furyl)phenylphosphonium derivatives. [29] This observation is surprising because the lower electron density of the corresponding $\mathrm{P}-\mathrm{C}$ bond due to the replacement of a phenyl group by an electron withdrawing substituent like furyl should increase the $\mathrm{P}-\mathrm{C}$ bonds length. On the other hand, theoretical calculations performed on related phospho- 
Table 1. Selected Bond Lengths $[\AA]]$ and Bond Angles $\left[{ }^{\circ}\right]$ for Compound 2a

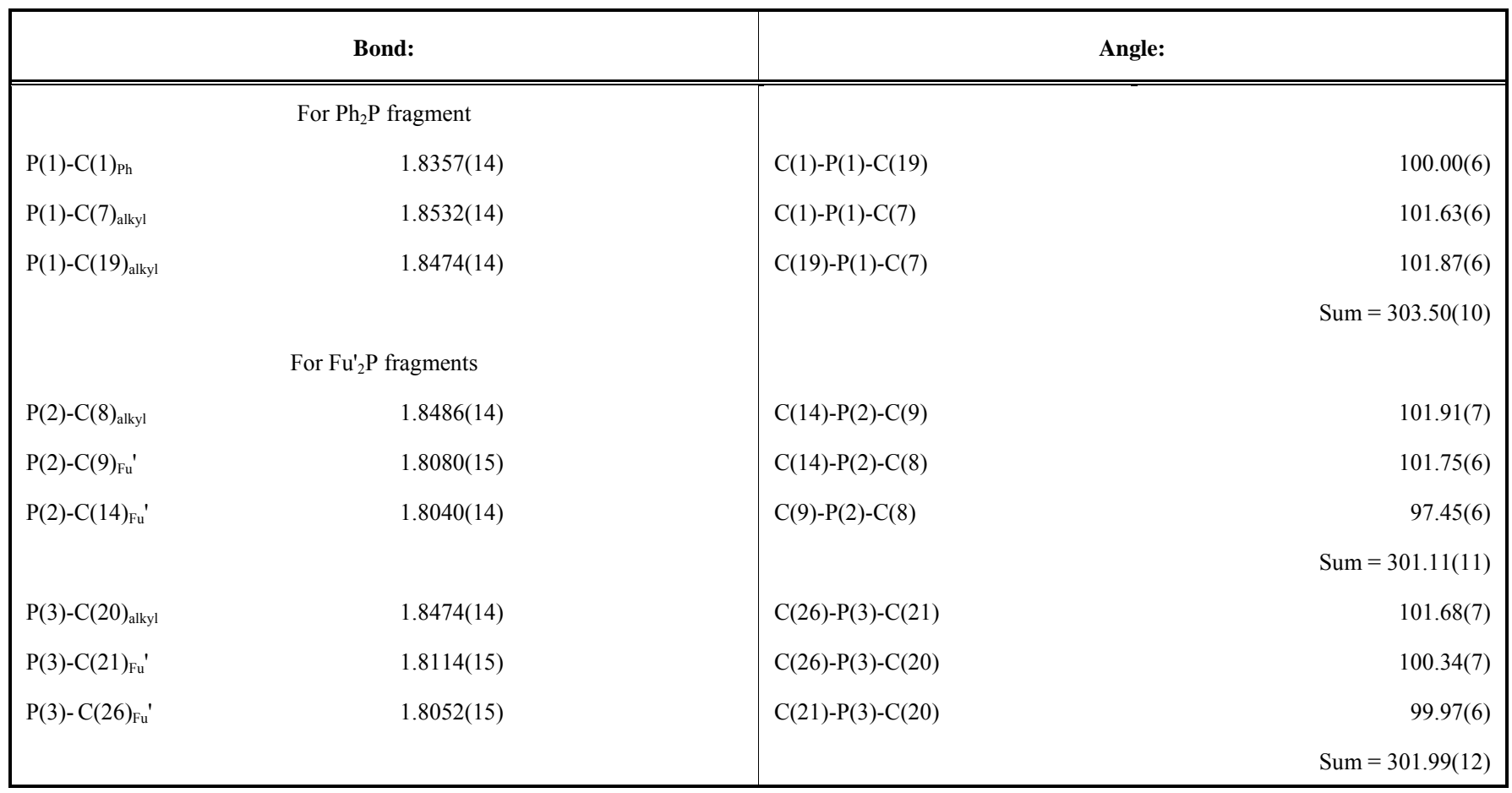

nium cations rationalize this unusual short $\mathrm{P}-\mathrm{C}$ bond length by a better orbital overlap in the case of furyl groups. [29]

\section{B. Synthesis of Palladium-triphosphine Pre-catalysts}

The well-known Triphos-palladium complex $\mathbf{4}$ was prepared by reaction between $\left[\mathrm{PdCl}_{2}(\mathrm{NCPh})_{2}\right]$ and the Triphos $\left[\left(\mathrm{Ph}_{2} \mathrm{PCH}_{2} \mathrm{CH}_{2}\right)_{2} \mathrm{PPh}\right]$ ligand 3 , according to literature reports. [24] The Triphosline-palladium complex 6 and 7 were similarly obtained starting from the lysidinyl- (or imidazolin1-yl-) triphosphine 5, and the Triphosfurane ligand 2a respectively (Scheme 2). [23]

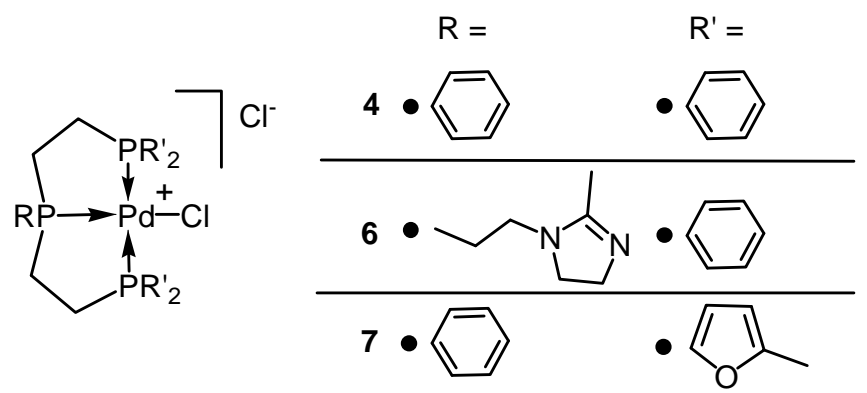

Scheme. (2).

The corresponding halide free complex 8 (see Scheme 3) was obtained from 4 by a further reaction with silver triflate. [30] In order to examine the effect of the counter-anion on the catalytic properties, we have also synthesized a new halide free Triphos-palladium complex 9 by a one-pot synthesis using $\mathrm{TlPF}_{6}$ as an halide abstracting reagent. The tridentate coordination mode in complex 9 was indicated by the existence in the ${ }^{31} \mathrm{P}$ NMR spectrum of a triplet at $110.3 \mathrm{ppm}$ and a doublet at $45.7 \mathrm{ppm}$. These chemical shifts correspond respectively to internal and external phosphorus groups, consistently with the analogous palladium complex bearing $\mathrm{BF}_{4}{ }^{-}$counter-anion. [31]

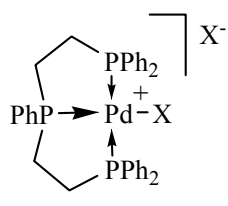

$8(\mathrm{X}=\mathrm{OTf})$

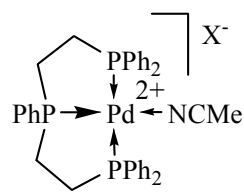

$9\left(\mathrm{X}=2 \mathrm{PF}_{6}\right)$
Scheme. (3).

In contrast to Trisphos-palladium complex $\mathbf{8}$, the addition of AgOTf to 6 in similar conditions led in the ${ }^{31} \mathrm{P}$ NMR spectrum to several multiplets around $97 \mathrm{ppm}$ and between 56 and $50 \mathrm{ppm}$, which likely result from the decomposition of complex 10, see Scheme 4.

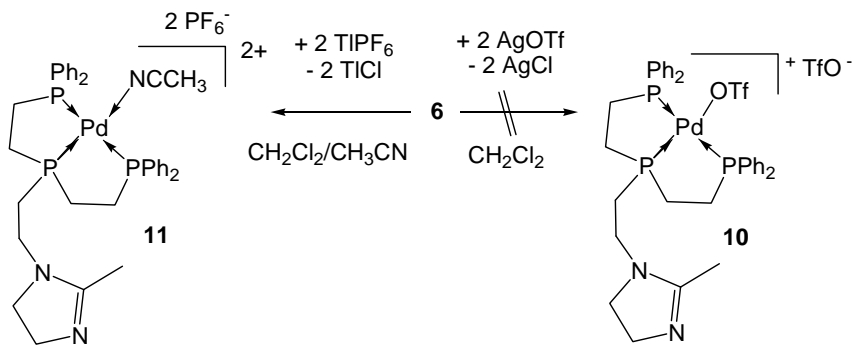

Scheme. (4).

Nonetheless, when $\mathrm{TlPF}_{6}$ in $\mathrm{CH}_{3} \mathrm{CN} / \mathrm{CH}_{2} \mathrm{Cl}_{2}$ was used instead of the above mentioned silver salt, a single complex was formed and identified as complex 11 ( see Scheme 4) with ${ }^{31} \mathrm{P}$ NMR signals at $107.9,30.7$ and $-144.3 \mathrm{ppm}$ in a 1:2:2 ratio. Complex 11 could be very useful as precursor for 
further alkylation or protonation reactions at the imidazoline ring, which should enhance the immobilizing ability in ionic liquids of the resulting functionalized Triphosphine.

Table 2. Crystal Data and Structure Refinement for Compound 2a

\begin{tabular}{|c|c|}
\hline Formula & $\mathrm{C}_{30} \mathrm{H}_{33} \mathbf{P}_{3} \mathbf{O}_{4}$ \\
\hline M & 550.47 \\
\hline $\mathrm{T} ; \mathrm{K}$ & $115(2)$ \\
\hline Crystal system & Triclinic \\
\hline Space group & $\mathrm{P}-1$ \\
\hline $\mathrm{a} ; \AA$ & $8.3575(2)$ \\
\hline $\mathrm{b} ; \AA$ & $11.1580(2)$ \\
\hline $\mathrm{c} ; \AA$ & $15.6437(2)$ \\
\hline$\alpha ;^{\circ}$ & $96.332(1)$ \\
\hline$\beta ;^{\circ}$ & $92.057(1)$ \\
\hline$\gamma ;{ }^{\circ}$ & $98.697(1)$ \\
\hline $\mathrm{V} ; \AA^{3}$ & $1431.20(5)$ \\
\hline $\mathrm{Z}$ & 2 \\
\hline $\mathrm{F}(000)$ & 580 \\
\hline$D_{\text {calc }} ; g / \mathrm{cm}^{3}$ & 1.277 \\
\hline diffractometer & Enraf-Nonius KappaCCD \\
\hline scan type & mixture of $\phi$ rotations and $\omega$ scans \\
\hline$\lambda ; \AA$ & 0.71073 \\
\hline$\mu ; \mathrm{mm}^{-1}$ & 0.241 \\
\hline Crystal size; $\mathrm{mm}^{3}$ & $0.325 \times 0.215 \times 0.075$ \\
\hline $\sin (\theta) / \lambda \max ; \AA^{-1}$ & 0.65 \\
\hline \multirow[t]{3}{*}{ Index ranges } & $\mathrm{h}:-10 ; 10$ \\
\hline & $\mathrm{k}:-14 ; 14$ \\
\hline & 1: $-20 ; 20$ \\
\hline $\mathrm{RC}=$ Refl. Collected & 12329 \\
\hline $\mathrm{IRC}=$ independent $\mathrm{RC}$ & $6516[\mathrm{R}(\mathrm{int})=0.0157]$ \\
\hline $\mathrm{IRCGT}=\mathrm{RC}$ and $[\mathrm{I}>2 \sigma(\mathrm{I})]$ & 6002 \\
\hline Refinement method & Full-matrix least-squares on $\mathrm{F}^{\wedge} 2$ \\
\hline Data / restraints / parameters & $6516 / 0 / 338$ \\
\hline $\mathrm{R}$ for IRCGT & $\mathrm{R} 1^{\mathrm{a}}=0.0348, \mathrm{wR} 2^{\mathrm{b}}=0.0833$ \\
\hline $\mathrm{R}$ for IRC & $\mathrm{R} 1^{\mathrm{a}}=0.0387, \mathrm{wR} 2^{\mathrm{b}}=0.0859$ \\
\hline Goodness-of-fit ${ }^{\mathrm{c}}$ & 1.062 \\
\hline Largest diff. peak and hole; e. $\AA^{-3}$ & 0.433 and -0.242 \\
\hline
\end{tabular}

${ }^{a} \mathrm{R} 1=\Sigma\left(\left|\mathrm{F}_{\mathrm{o}}\right|-\mid \mathrm{F}_{\mathrm{c}} \|\right) / \Sigma\left|\mathrm{F}_{\mathrm{o}}\right| \cdot{ }^{\mathrm{b}} \mathrm{wR} 2=\left[\sum \mathrm{w}\left(\mathrm{F}_{\mathrm{o}}{ }^{2}-\mathrm{F}_{\mathrm{c}}{ }^{2}\right)^{2} / \Sigma\left[\mathrm{w}\left(\mathrm{F}_{\mathrm{o}}{ }^{2}\right)^{2}\right]^{1 / 2}\right.$ where $\mathrm{w}=1 /\left[\sigma^{2}\left(\mathrm{Fo}^{2}\right)+1.0792\right.$ $\left.\mathrm{P}+(0.0270 \mathrm{P})^{2}\right]$ where $\mathrm{P}=\left(\operatorname{Max}\left(\mathrm{Fo}^{2}, 0\right)+2 * \mathrm{Fc}^{2}\right) / 3 .{ }^{\mathrm{c}}$ Goodness of fit $=\left[\Sigma \mathrm{w}\left(\mathrm{F}_{\mathrm{o}}{ }^{2}-\mathrm{F}_{\mathrm{c}}\right)^{2} /\left(\mathrm{N}_{\mathrm{o}}-\right.\right.$ $\left.\mathrm{N}_{\mathrm{v}}\right]^{1 / 2}$.
In contrast to complexes $\mathbf{4}$ and $\mathbf{6}$, complex $\mathbf{7}$ in the presence of $\mathrm{TlPF}_{6}$ in a $\mathrm{CH}_{2} \mathrm{Cl}_{2} / \mathrm{CH}_{3} \mathrm{CN}$ solvent mixture was partially converted to the corresponding halide free complex 12 , which is characterized in its ${ }^{31} \mathrm{P}$ NMR spectrum by the presence of a new doublet at $11.2 \mathrm{ppm}$ and triplet at $117.0 \mathrm{ppm}$. However, in pure acetonitrile the reaction becomes almost complete.

Since the $\mathrm{TlCl}$ formed during this halide abstraction reaction is slightly soluble by addition of dichloromethane to the reaction mixture, we suggest that the presence of the four furyl electron withdrawing groups in complex 12 significantly increase the metal electrophilic character which then reacts with traces of chloride anion. From a catalytic perspective the activity of complex 12 should not be altered by small amount of complex 7 since this one was found to be totally inactive in alkynes methoxylation.

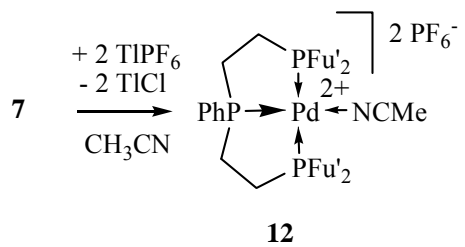

Equation. (2).

\section{Catalytic Results in the Intermolecular Methoxylation of Alkynes}

Since the above mentioned cationic Triphos-palladium complex 8 effectively catalyzes the conversion of phenylacetylene into dimethylacetal derivatives in methanol solvent, we thus started our catalytic studies using complex 8 under analogous conditions but in a $1: 1$ mixture of $\mathrm{CH}_{3} \mathrm{OH} /$ $[\mathrm{BMIM}]\left[\mathrm{BF}_{4}\right]$ in view of performing catalyst recycling. ${ }^{1} \mathrm{H}$ NMR monitoring of the reaction in $\mathrm{CD}_{3} \mathrm{OD}$ clearly showed the beneficial effect of the ionic liquid on the activity and chemoselectivity of alkoxylation reaction. Indeed, in this solvent mixture, a complete conversion of starting material is obtained after six days corresponding to a turnover number (TON) of 424. Five percent of acetophenone were detected in the products formed as a consequence of acetal hydrolysis by persistent traces of water in the catalytic medium. Conversely, seven days of reaction were required in pure methanol at $25{ }^{\circ} \mathrm{C}$ and the amount of acetophenone formed was doubled. In the next reactions the catalytic runs were thus stopped before complete conversion was achieved to better identify weak variations of activity in recycling experiments. For instance, in a first run after five days, $81 \%$ conversion of starting material was obtained with a TON $=322$. Catalytic results of methoxylation of phenylacetylene with the above complexes 8 and $\mathbf{9}$ are summarized in Fig. 3. These results evidence an unexpected strong influence of the counteranion on the activity and stability of the palladium catalysts.

Complex 8 exhibits a slightly better activity than $\mathbf{9}$ in the first catalytic run ( $81 \%$ versus $75 \%)$. However, this activity dramatically decreases of practically $50 \%$ after each run. Although precursor $\mathbf{9}$ was less active than $\mathbf{8}$, the lifetime of its related catalytic species is greater and allows doubling the total turnover number compared to $\mathbf{8}$, with a value of about 


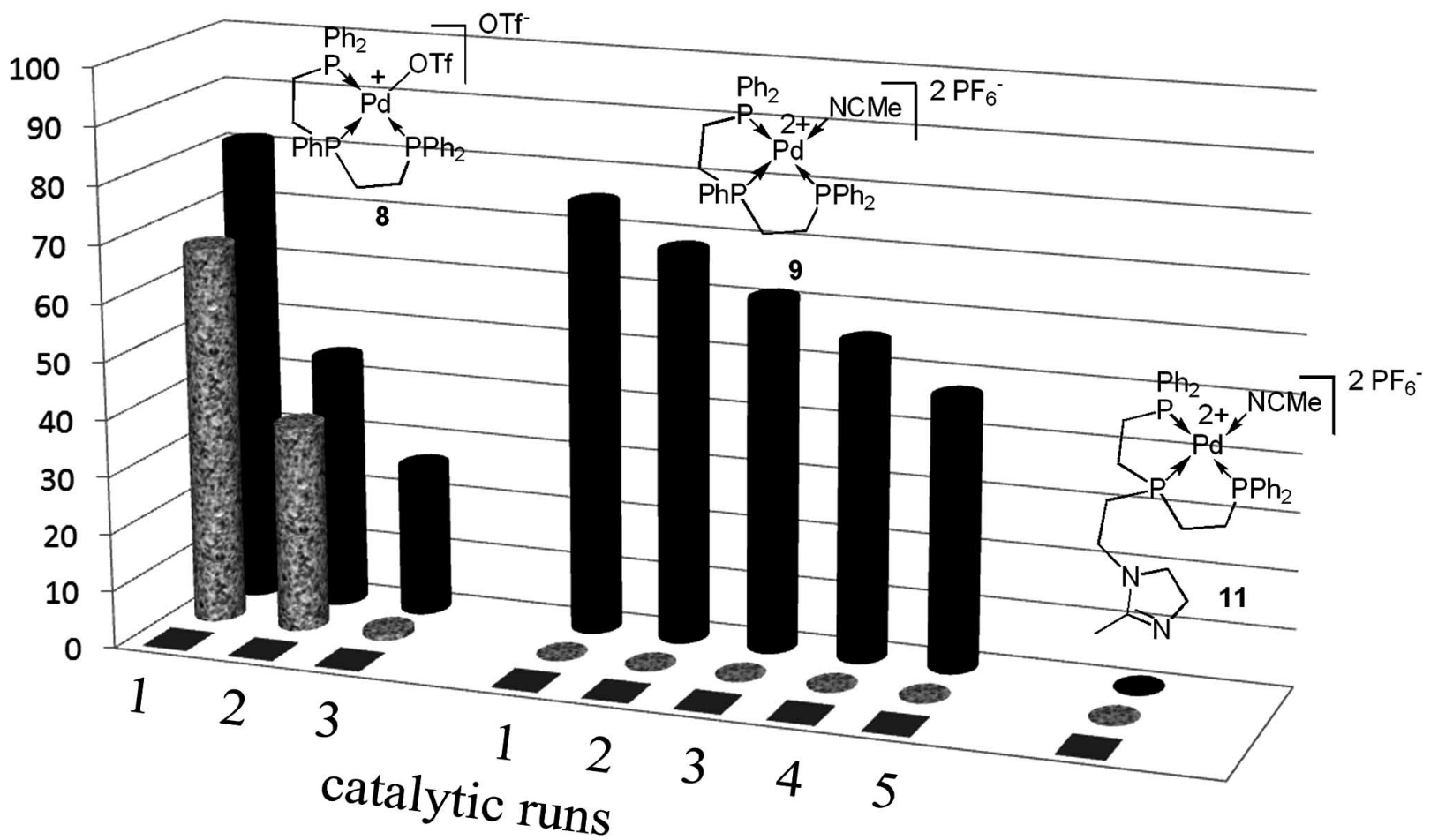

Fig. (3). Phenylacetylene methoxylation with recovered $\mathrm{Pd}$ catalysts in $[\mathrm{BMIM}]\left[\mathrm{BF}_{4}\right]$. Conversion of phenylacetylene in mol\% $(\bullet$ black cylinder in the background), 1-octyne ( grained cylinder), 1-phenyl-1-propyne ( $\mathbf{a}$ grey square in the foreground) and performances of the recovered ionic liquid phase, determined by proton $\mathrm{NMR}$ in $\mathrm{CDCl}_{3}$, with complexes $\mathbf{8}, \mathbf{9}$ and 11. Conditions: alkyne (4.55 mmol), precatalyst $(0.2 \mathrm{~mol} \%),[\mathrm{BMIM}]\left[\mathrm{BF}_{4}\right](0.5 \mathrm{ml}), \mathrm{CH}_{3} \mathrm{OH}(0.5 \mathrm{ml}), 5$ days, $25^{\circ} \mathrm{C}$.

$1.25 \times 10^{3}$ mole of acetal per mole of $\mathbf{9}$ after five recycling runs. This clearly demonstrates the potential of catalytic systems incorporating 9 towards continuous-flow catalytic processes. Conversely, no activity was observed from Triphosline-palladium pre-catalyst $\mathbf{1 1}$. This could be a consequence of the lower electrophilic character of metal in complex 11 compared to 9 which is induced by the electrondonating dangling imidazole fragment and/or by its eventual coordination to the metallic species.

Although the drop of activity observed from recycling experiments with 9 is limited to seven percent after each catalytic run this might still remain too important for sustainable processes applications. We have subsequently performed additional experiments to determine the origin of this catalyst deactivation. While no ICP MS experiments were performed so far on the organic extracting solvent, the ligand-metal leaching is however excluded because it was not detected by proton NMR spectroscopy in extracting heptane phases. We then anticipated a slow decomposition of active species in the ionic liquid even at room temperature. So, the ionic liquid containing pre-catalyst 9 recovered after five successive catalytic experiments was left aside during five weeks at room temperature. After this inactivity period, phenylacetylene and methanol were then introduced and conversions of ca. 20 and $10 \%$ were respectively found after the first and second recycling. These values are very close to those extrapolated at the $10^{\text {th }}$ and $11^{\text {th }}$ catalytic runs, if the recovered catalyst had been reused constantly during these five weeks. This experiment proves unambiguously that the drop of activity is consistent with a very slow deactivation process over time. Fig. (3) seems to indicate that catalytic systems based on complexes $\mathbf{8}$ and $\mathbf{9}$ deactivate in two different manners. In the case of complex $\mathbf{8}$, the decomposition rate is consistent with a first-order kinetic in catalyst concentration since the logarithm of the conversion changes in a linear manner with time. Conversely, this deactivation appears to be zero order in catalyst concentration in the case of complex 9, as shown in Fig. (3) from the linear decrease of conversion. The deactivation in this later case could be then correlated to physical or chemical properties of the catalytic medium which may evolve with time, either by slow introduction of air or moisture, or by the presence of residual methanol. In the case of complex $\mathbf{8}$, a slow reaction between traces of zerovalent palladium with the ionic liquid (palladium-carbene formation) may also indirectly decrease the catalyst concentration. Additional investigations are in progress to find out the origin of these deactivation processes.

When the electron-rich unactivated alkyne 1-octyne was used instead of phenylacetylene, in the presence of palladium pre-catalysts $\mathbf{8}, \mathbf{9}$ and $\mathbf{1 1}$, we observed that only complex $\mathbf{8}$ effectively promotes the conversion of 1-octyne into the corresponding acetal with $66 \%$ yield in the first run. However, a rapid drop of conversion was observed, as previously obtained with phenylacetylene as substrate, see Fig. (3). The result concerning pre-catalyst $\mathbf{9}$ was surprising since it was active in methoxylation of phenylacetylene. We also noted that all the palladium pre-catalysts of our study remained inactive towards 1,2-disubstituted alkynes such as 1-phenyl1-propyne. 


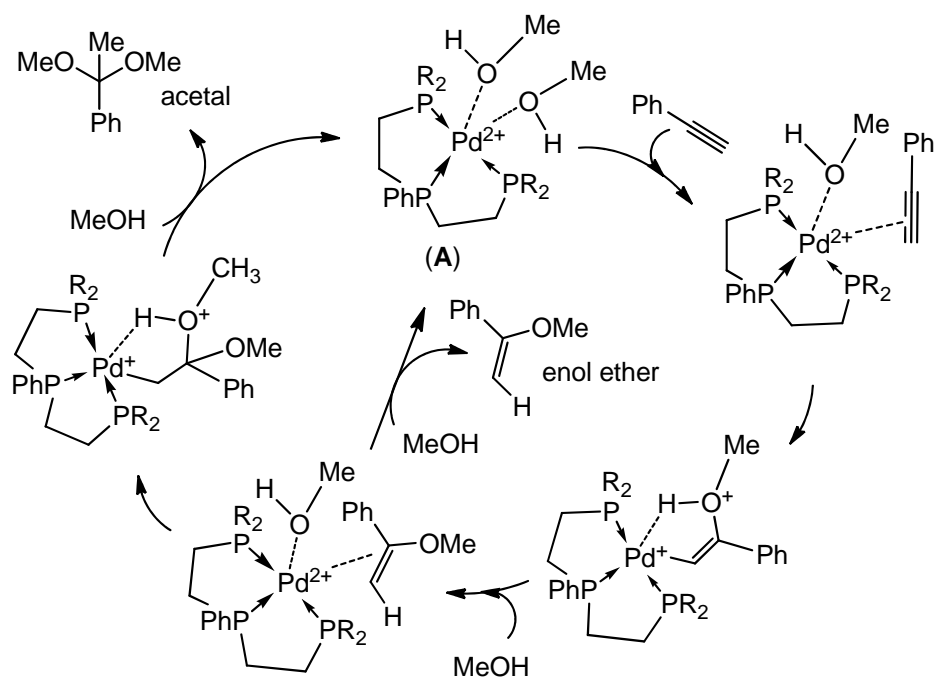

(B)

Scheme. (5). Concomitant formation of enol ether and acetal from methanol and alkyne.

To find out the reasons of these unexpected results, we started to investigate the mechanism of this reaction. The above-reported observations could be hardly correlated with the electrophilicity of the palladium metal centre which depends on the phosphine and counter-anion nature. To the best of our knowledge, mainly two different mechanisms have been proposed and discussed for this $\mathrm{C}-\mathrm{O}$ bond formation. The first one is based on the addition of oxygenated nucleophiles, such as water or alcohols, to the coordinated alkyne inside [16] or outside [12] the metal coordination sphere. In our study, the fact that the rate of methanol addition onto the coordinated alkyne is lower when the phenyl group in Triphos is replaced by an electron-donating alkyl fragment in Triphosline is consistent with this mechanism. This assumption is confirmed by the higher conversion obtained with pre-catalyst 8 in the case of electron-poor alkynes such as phenylacetylene when compared to 1-octyne. Nevertheless, a second mechanism based on a $\sigma$-alkynylpalladium intermediate [21] might also explain the ineffectiveness of all our palladium pre-catalysts towards the activation of 1,2-disubstituted alkynes such as 1-phenyl-1-propyne. It is however dismissed because there are not yet reasonable catalytic pathways allowing the releasing of enolether by an unlikely methanol addition to a covalent $\mathrm{Pd}-\mathrm{C}$ bond. A third mechanism which involves as key step the protonation of a $\eta^{2}$-diyne $\operatorname{Pd}(0)$ complex should also be mentioned, [32, 33] but it was also excluded in the discussion because no acidic compound or zerovalent palladium species is present in our catalytic system.

The impact of electron-withdrawing groups in the Triphos ligand on activity and selectivity of palladium precatalysts was investigated. The catalytic properties of $\mathbf{1 2}$ were examined and compared to those found with the cationic Triphos-palladium complex 9. After five days in neat methanol at room temperature, we found rather similar conversions of phenylacetylene with $51 \%$ for $\mathbf{1 2}$ and $57 \%$ for $\mathbf{9}$. This result was disappointing and did not fit our previsions in terms of activity enhancement. We discovered that the selectivity is, conversely, much more sensitive to slight variations of electrophilic character at the metal center. In- deed, the bis-addition $\left[\mathrm{PhC}(\mathrm{OMe})_{2} \mathrm{CH}_{3}\right] /$ mono-addition $\left[\mathrm{PhC}(\mathrm{OMe})_{2} \mathrm{CH}_{3}\right]$ products ratio was found to be 2.4 with complex 12, while under identical conditions it was of 6.1 with complex $\mathbf{9}$.

In view of getting more mechanistic insights, a phosphorus NMR spectroscopy monitoring was performed with complex 12 in the presence of either five equivalents of phenylacetylene or methanol in $\mathrm{CDCl}_{3}$. In both cases, signals of complex 12 at 117.1 and $11.2 \mathrm{ppm}$ were fully replaced by new triplets at 116.2 and $10.6 \mathrm{ppm}$ and new doublets at 115.2 and $9.9 \mathrm{ppm}$, respectively. This attests that methanol and phenylacetylene can both easily coordinate palladium centers. Since the $\Delta \delta_{\mathrm{P}}$ for the palladium species coordinating methanol is higher than the $\Delta \delta_{\mathrm{P}}$ for palladium species coordinating phenylacetylene, a stronger ligand-metal interaction is attributed to methanol-palladium. Therefore, a favored thermodynamic intermediate for the first coordination to the metal is assumed to incorporate the alcohol preferentially instead of the alkyne, leading to complex (A) which is similar to those reported in the methoxycarbonylation of ethane, [33] see Scheme 5. This is perfectly consistent with a cationic Trisphosfurane-palladium catalysts behaving similarly to the Lewis acid monophosphine gold catalyst. [16] Additional NMR kinetic experiments mixing phenylacetylene and methanol resulted in very quick modification of complexes at the NMR time-scale and did not allow any easy interpretation. Consistently with the NMR spectroscopic observations and above mentioned catalytic cycles, we depict the concomitant formation of mono- and bis-addition products in Scheme 5.

After replacement of one coordinated methanol by a phenylacetylene molecule, an inner nucleophilic attack of the alcohol to the $\mathrm{C}-\mathrm{C}$ triple bond takes place to form the carbopalladated complex. A further internal protonation of the $\mathrm{Pd}-\mathrm{C}$ bond as previously described with analogous gold complexes [16] would lead to complex (B). The active species (A) could be regenerated by direct releasing of the mono-addition product or by a second methanol nucleophilic addition followed by the bis-addition product release. 
It is interesting to note that the different enol ether/acetal ratios found of 2.4 and 6.1 with complexes $\mathbf{9}$ and $\mathbf{1 2}$ respectively are correlated to the electrophilic character of the palladium center which depends on the P-substituents. Indeed, in the case where the triphosphine ligand bears the four electron-withdrawing furyl groups, the strength of the methanol-palladium interaction is enhanced. Subsequently, the enol ether elimination and its replacement by methanol could be favored against the second $\mathrm{C}-\mathrm{O}$ bond formation. This effect would annihilate the expected beneficial effect of the presence of the electron-poor triphosphine ligand, as shown by the slightly decreased activity observed with the related Triphosfurane-palladium catalyst.

To summarize, the electron-withdrawing ligand does not alter the activity of palladium catalyst in the methoxylation of alkynes but enhances the productivity in mono-addition product. Further studies are under investigation to confirm these proposals and in particular theoretical calculations could help in this purpose.

\section{CONCLUSION}

Cationic palladium complexes containing the linear triphosphine ligands Triphos, Trisphosline, Triphosfurane were studied as catalytic precursors in the methoxylation of aromatic and aliphatic-substituted alkynes. In the case of the Triphos ligand, a complete conversion of phenylacetylene was achieved with only $0.2 \%$ of pre-catalyst $[\mathrm{Pd}($ Triphos) $\mathrm{NCMe}]\left[\left(\mathrm{PF}_{6}\right)_{2}\right]$ in a methanol/[BMIM] $\left[\mathrm{BF}_{4}\right]$ mixture. We discovered that the addition of an ionic liquid to pure methanol allowed not only to increase the activity of the palladium catalyst but also to provide a recyclable catalyst which can be reused more than a dozen times with a drop of activity of only $1 \%$ per day. This activity decreasing being zero-order in catalyst concentration we believe that it is due to evolution of physical/chemical properties of the catalytic medium in the course of recycling runs.

In an effort to further improve these catalytic performances, the first example of poor $\sigma$-electron-donating/strong $\pi$-electron-acceptor linear triphosphine, named Triphosfurane $\left[\mathrm{PhP}\left(\mathrm{CH}_{2} \mathrm{CH}_{2} \mathrm{PFu}_{2}^{\prime}\right)_{2}\right]$, has been prepared and fully characterized by NMR spectroscopy and X-ray diffraction. It has been obtained with high selectivity at low temperature from a novel vinyldifurylphosphine reagent and phenylphosphine in the presence of AIBN under irradiation conditions. Such specific conditions are required because the introduction of furyl groups onto vinylfurylphosphine affects strongly its reactivity towards radical species. Upon palladium coordination, we found that the presence of electronwithdrawing groups in Triphos plays an important role on the selectivity of the phenylacetylene methoxylation without altering the activity. The performances of recovered ionic liquid described in the present study show for the first time that P-tridentate ligands exhibit excellent metalimmobilizing abilities in ionic liquids, and may lead to efficient catalytic systems, selective and benign for environment.

\section{ACKNOWLEDGMENTS}

We thank Dr. Bernard Hanquet for phosphorus NMR spectra simulations with $g \mathrm{NMR}$ software and the Ministère de l'Enseignement Supérieur et de la Recherche for support and for a PhD fellowship to $\mathrm{S}$. S. We also thank the Région Bourgogne (PARI STM 08), the Universite de Bourgogne, the Centre National de la Recherche Scientifique and the CP2D program "Chimie pour le développement durable" (RDR2) for financial support of this work.

\section{EXPERIMENTAL SECTION}

General Procedures. All reactions were performed in Schlenk-type flasks under an argon atmosphere. Solvents were purified and dried by conventional methods and distilled under argon. All analysis were performed at the "Plateforme d'Analyses Chimiques et de Synthèse Moléculaire de l'Université de Bourgogne" (PACSMUB). ${ }^{1} \mathrm{H},{ }^{31} \mathrm{P}\left\{{ }^{1} \mathrm{H}\right\}$ and ${ }^{13} \mathrm{C}\left\{{ }^{1} \mathrm{H}\right\}$ NMR spectra were recorded at $298 \mathrm{~K}$ on a Bruker 300 Avance spectrometer. All chemical shifts are relative to $\mathrm{SiMe}_{4}$ (for ${ }^{1} \mathrm{H}$ and ${ }^{13} \mathrm{C}$ NMR spectroscopy) and $85 \% \mathrm{H}_{3} \mathrm{PO}_{4}$ (for ${ }^{31} \mathrm{P}$ NMR spectroscopy) and are given in ppm. Mass spectra were obtained on a Bruker micrOTOF-Q ESI-MS spectrometer. The elemental analyses were performed on a Fisons EA 1108 CHNS-O apparatus. The Triphos 3, AgOTf, $\mathrm{TlPF}_{6}$, acetonitrile, phenylacetylene, and 1-octyne were commercial products and were used as received. The bis(5methyl-2-furyl)bromophosphine $\left(\mathrm{Fu}_{2}{ }_{2} \mathrm{PBr}\right)$, ionic liquid $[\mathrm{BMIM}]\left[\mathrm{BF}_{4}\right]$ were prepared according to the literature $[26$, 34]. The solids (catalyst and reagents) and the ionic liquid were degassed under vacuum before use. Ligand $\mathbf{5}$ and complexes $\left[\mathrm{PdCl}_{2}(\mathrm{NCPh})_{2}\right], \mathbf{4}, \mathbf{6}$ and 8 were prepared according to the literature. [35, 21, 23]

\section{Synthesis of Vinyldifurylphosphine 1}

A solution of $\mathrm{Fu}_{2}{ }_{2} \mathrm{PBr}(3.17 \mathrm{~g}, 11.6 \mathrm{mmol})$ in $10 \mathrm{ml}$ of THF was slowly added to vinyl magnesium chloride (8.71 $\mathrm{ml}, 1.6 \mathrm{~mol}^{-1} \mathrm{l}^{-1}$ in THF) at room temperature. The resulting yellow green solution was stirred for 3.5 hours. The reaction was hydrolyzed by $10 \mathrm{ml}$ of degassed water and the solvent was removed under vacuum. The product 1 was extracted by $10 \times 10 \mathrm{~mL}$ of $\mathrm{CH}_{2} \mathrm{Cl}_{2}$. The resulting solution was dried over $\mathrm{MgSO}_{4}$ and filtrated over Celite ${ }^{\circledR}$. Evaporation of solvent led to an orange viscous oil $(2.35 \mathrm{~g}, 92 \%) .{ }^{1} \mathrm{H}$ NMR $\delta\left(\mathrm{CDCl}_{3}\right)$ $=6.67\left(\mathrm{dd}, 2 \mathrm{H}, J_{\mathrm{H}, \mathrm{H}}=J_{\mathrm{P}, \mathrm{H}}=3 \mathrm{~Hz}, \mathrm{H}^{4}\right), 6.65\left(\mathrm{ddd}, 1 \mathrm{H}, \mathrm{H}^{\mathrm{c}}\right.$, $\left.J_{\mathrm{H}, \mathrm{H}}^{\mathrm{c}}=12 \mathrm{~Hz}, J_{\mathrm{H}, \mathrm{H}}^{\mathrm{c}}=15 \mathrm{~Hz}, J_{\mathrm{P}, \mathrm{H}}{ }^{\mathrm{c}}=24 \mathrm{~Hz}\right), 6.00\left(\mathrm{~m}, 2 \mathrm{H}, \mathrm{H}^{3}\right)$, 5.82 (ddd, H, H $\mathrm{H}^{\mathrm{b}}, J_{\mathrm{H}, \mathrm{H}}^{\mathrm{b}}{ }^{\mathrm{c}}=12 \mathrm{~Hz}, J_{\mathrm{H}, \mathrm{H}}^{\mathrm{b}}=2 \mathrm{~Hz},{ }^{2} J_{\mathrm{P}, \mathrm{H}}^{\mathrm{b}}=33 \mathrm{~Hz}$ ), $5.64\left(\mathrm{ddd}, \mathrm{H}, \mathrm{H}^{\mathrm{a}}, J_{\mathrm{H}, \mathrm{H}}^{\mathrm{a}}=15 \mathrm{~Hz}, J_{\mathrm{H}, \mathrm{H}}^{\mathrm{a}}=2 \mathrm{~Hz},{ }^{2} J_{\mathrm{P}, \mathrm{H}}{ }^{\mathrm{a}}=18 \mathrm{~Hz}\right)$, $2.34\left(\mathrm{~s}, 6 \mathrm{H}, \mathrm{CH}_{3}\right) .{ }^{13} \mathrm{C}\left\{{ }^{1} \mathrm{H}\right\} \mathrm{NMR} \delta\left(\mathrm{CDCl}_{3}\right)=157.24(\mathrm{~d}, 2 \mathrm{C}$, $\left.{ }^{4} J_{\mathrm{P}, \mathrm{C}}=2 \mathrm{~Hz}, \mathrm{C}^{5}\right), 148.50\left(\mathrm{~d}, 2 \mathrm{C}, J_{\mathrm{P}, \mathrm{C}}=8 \mathrm{~Hz}, \mathrm{C}^{2}\right), 133.52(\mathrm{~d}$, $\left.1 \mathrm{C}, J_{\mathrm{P}, \mathrm{C}}=3 \mathrm{~Hz}, \mathrm{CH}_{(\mathrm{viny})}\right), 127.86\left(\mathrm{~d}, 1 \mathrm{C},{ }^{2} J_{\mathrm{P}, \mathrm{C}}=22 \mathrm{~Hz}\right.$, $\left.\mathrm{CH}_{2 \text { (vinyl) }}\right), 121.73\left(\mathrm{~d}, 2 \mathrm{C},{ }^{2} \mathrm{~J}_{\mathrm{P}, \mathrm{C}}=24 \mathrm{~Hz}, \mathrm{C}^{3}\right), 107.05(\mathrm{~d}, 2 \mathrm{C}$, $\left.{ }^{3} J_{\mathrm{P}, \mathrm{C}}=6 \mathrm{~Hz}, \mathrm{C}^{4}\right), 13.85\left(\mathrm{~s}, 2 \mathrm{C}, \mathrm{CH}_{3}\right) .{ }^{31} \mathrm{P}\left\{{ }^{1} \mathrm{H}\right\} \mathrm{NMR} \delta$ $\left(\mathrm{CDCl}_{3}\right)=-57.03(\mathrm{~s})$. Satisfactory elemental analysis could not be obtained due to its waxy nature and high airsensitivity.

\section{Synthesis of Triphosfurane 2a and Isomers $\mathbf{2 b}, \mathbf{b}^{\prime}$}

A mixture of 1 (303 mg, $1.37 \mathrm{mmol}$ ), phenylphosphine $(83 \mu \mathrm{L}, 0.75 \mathrm{mmol})$ and AIBN (12.4 $\mathrm{mg}, 0.075 \mathrm{mmol})$ was cooled to $4{ }^{\circ} \mathrm{C}$ and irradiated at this temperature with quartz jacketed high-pressure mercury lamp during 18 hours under stirring. The ligand 2a was obtained as white oil contaminated by traces of $\mathbf{2 b , b}$ ' (304 mg, 90 \%). After several days 
at room temperature, pure ligand $\mathbf{2 a}$ was obtained as colorless crystals suitable for X-ray analysis. Data for $2 \mathrm{a}:{ }^{1} \mathrm{H}$ $\operatorname{NMR} \delta\left(\mathrm{CDCl}_{3}\right)=7.42\left(\mathrm{~m}, 2 \mathrm{H}, \mathrm{H}_{\mathrm{Ph}}\right), 7.12\left(\mathrm{~m}, 3 \mathrm{H}, \mathrm{H}_{\mathrm{Ph}}\right), 6.72$ $\left(\mathrm{m}, 4 \mathrm{H}, \mathrm{H}^{4}\right), 5.80\left(\mathrm{~m}, 4 \mathrm{H}, \mathrm{H}^{3}\right), 2.43\left(\mathrm{~m}, 4 \mathrm{H}, \mathrm{CH}_{2} \mathrm{P}_{\text {int }}\right), 2.03(\mathrm{~s}$, $\left.6 \mathrm{H}, \mathrm{CH}_{3}\right), 2.01\left(\mathrm{~s}, 6 \mathrm{H}, \mathrm{CH}_{3}\right), 1.91\left(\mathrm{~m}, 4 \mathrm{H}, \mathrm{CH}_{2} \mathrm{P}_{\text {ext }}\right) .{ }^{13} \mathrm{C}\left\{{ }^{1} \mathrm{H}\right\}$ NMR $\delta\left(\mathrm{CDCl}_{3}\right)=157.24\left(\mathrm{~d}, 4 \mathrm{C},{ }^{4} J_{\mathrm{P}, \mathrm{C}}=1 \mathrm{~Hz}, \mathrm{C}^{5}\right), 150.03$ $\left(\mathrm{dd}, 4 \mathrm{C}, J_{\mathrm{P}, \mathrm{C}}=17 \mathrm{~Hz},{ }^{4} J_{\mathrm{P}, \mathrm{C}}=10 \mathrm{~Hz}, \mathrm{C}^{2}\right), 138.17\left(\mathrm{~d}, 2 \mathrm{C},{ }^{3} J_{\mathrm{P}, \mathrm{C}}\right.$ $\left.=19 \mathrm{~Hz}, \mathrm{C}_{\mathrm{Ph}}^{3}\right), 132.17\left(\mathrm{~d}, 2 \mathrm{C},{ }^{2} J_{\mathrm{P}, \mathrm{C}}=20 \mathrm{~Hz}, \mathrm{C}_{\mathrm{Ph}}^{2}\right), 128.39$ $\left(\mathrm{dd}, 4 \mathrm{C}, J_{\mathrm{P}, \mathrm{C}}=23 \mathrm{~Hz},{ }^{4} J_{\mathrm{P}, \mathrm{C}}=16, \mathrm{C}_{\mathrm{Ph}}^{1}\right), 121.51\left(\mathrm{dd}, 4 \mathrm{C},{ }^{2} J_{\mathrm{P}, \mathrm{C}}\right.$ $\left.=25 \mathrm{~Hz},{ }^{5} J_{\mathrm{P}, \mathrm{C}}=16 \mathrm{~Hz}, \mathrm{C}^{3}\right), 107.03\left(\mathrm{~d}, 4 \mathrm{C},{ }^{3} J_{\mathrm{P}, \mathrm{C}}=6 \mathrm{~Hz}, \mathrm{C}^{4}\right)$, $24.03\left(\mathrm{t}, 2 \mathrm{C}, J_{\mathrm{P}, \mathrm{C}}=16 \mathrm{~Hz}, \mathrm{CH}_{2} \mathrm{P}_{\mathrm{ext}}\right), 21.79\left(\mathrm{dd}, 2 \mathrm{C}, J_{\mathrm{P}, \mathrm{C}}=\right.$ $\left.15 \mathrm{~Hz},{ }^{2} J_{\mathrm{P}, \mathrm{C}}=2 \mathrm{~Hz}, \mathrm{CH}_{2} \mathrm{P}_{\text {int }}\right), 13.44\left(\mathrm{~s}, 2 \mathrm{C}, \mathrm{CH}_{3}\right) .{ }^{31} \mathrm{P}\left\{{ }^{1} \mathrm{H}\right\}$ NMR $\delta\left(\mathrm{CDCl}_{3}\right)=-17.25\left(\mathrm{t}, 1 \mathrm{P}, \mathrm{P}_{\text {int }},{ }^{3} J_{\mathrm{P}, \mathrm{P}}=32 \mathrm{~Hz}\right),-58.92$ $\left(\mathrm{d}, 2 \mathrm{P}, \mathrm{P}_{\text {ext }},{ }^{3} J_{\mathrm{P}, \mathrm{P}}=32 \mathrm{~Hz}\right)$. Data for $\mathbf{2 b}$ identified by ${ }^{31} \mathrm{P}\left\{{ }^{1} \mathrm{H}\right\}$ NMR: $\delta\left(\mathrm{CDCl}_{3}\right)=-35.22\left(\mathrm{~d}, 1 \mathrm{P}, \mathrm{P}_{\mathrm{ext}},{ }^{3} J_{\mathrm{P}, \mathrm{P}}=33 \mathrm{~Hz}\right),-37.53$ $\left(\mathrm{t}, 1 \mathrm{P}, \mathrm{P}_{\text {int }},{ }^{3} J_{\mathrm{P}, \mathrm{P}}={ }^{2} J_{\mathrm{P}, \mathrm{P}}=33 \mathrm{~Hz}\right),-59.04\left(\mathrm{~d}, 1 \mathrm{P}, \mathrm{P}_{\text {ext }},{ }^{2} J_{\mathrm{P}, \mathrm{P}}=33\right.$ $\mathrm{Hz})$. Data for 2b' identified by ${ }^{31} \mathrm{P}\left\{{ }^{1} \mathrm{H}\right\}$ NMR: $\delta\left(\mathrm{CDCl}_{3}\right)=$ $-34.97\left(\mathrm{~d}, 1 \mathrm{P}, \mathrm{P}_{\mathrm{ext}},{ }^{3} J_{\mathrm{P}, \mathrm{P}}=33 \mathrm{~Hz}\right),-37.59\left(\mathrm{t}, 1 \mathrm{P}, \mathrm{P}_{\text {int }},{ }^{3} J_{\mathrm{P}, \mathrm{P}}=\right.$ $\left.{ }^{2} J_{\mathrm{P}, \mathrm{P}}=33 \mathrm{~Hz}\right),-59.09\left(\mathrm{~d}, 1 \mathrm{P}, \mathrm{P}_{\mathrm{ext}},{ }^{2} J_{\mathrm{P}, \mathrm{P}}=33 \mathrm{~Hz}\right)$. ESI-MS $\left(\mathrm{CH}_{2} \mathrm{Cl}_{2} / \mathrm{MeOH}\right) \mathrm{C}_{30} \mathrm{H}_{33} \mathrm{O}_{4} \mathrm{P}_{3}$ (550.16) found: $\mathrm{m} / \mathrm{z}=589.144$ $[\mathrm{M}+\mathrm{Na}+\mathrm{O}]^{+}$, simulated: 589.144. Anal. Calc: C, 65.49; H, 7.33. Found: $\mathrm{C}, 65.42 ; \mathrm{H}, 7.27$.

\section{Synthesis of Complex 7}

To a red suspension of $\mathrm{PdCl}_{2}(\mathrm{NCPh})_{2}(190.56 \mathrm{mg}, 0.49$ mmol) in $5 \mathrm{ml}$ of $\mathrm{CH}_{2} \mathrm{Cl}_{2}$ was slowly added a solution of triphosfurane (304 mg, $0.552 \mathrm{mmol}$ ) in $5 \mathrm{ml}$ of $\mathrm{CH}_{2} \mathrm{Cl}_{2}$. An orange suspension was immediately formed. After stirring for 2 hours at room temperature, the solvent was evaporated in vacuum. Addition of $10 \mathrm{ml}$ of $\mathrm{Et}_{2} \mathrm{O}$ afforded complex 11 as an orange powder which was washed twice with $\mathrm{Et}_{2} \mathrm{O}$ and dried for 2 hours $(312 \mathrm{mg}, 87 \%)$. ${ }^{1} \mathrm{H} \mathrm{NMR} \delta\left(\mathrm{CDCl}_{3}\right)=8.30$ $\left(\mathrm{m}, 2 \mathrm{H}, \mathrm{H}_{\mathrm{Ph}}\right), 7.51\left(\mathrm{~m}, 3 \mathrm{H}, \mathrm{H}_{\mathrm{Ph}}\right), 7.43\left(\mathrm{~d}, 2 \mathrm{H}, J_{\mathrm{H}, \mathrm{H}}=3 \mathrm{~Hz}, \mathrm{H}^{4}\right)$, $7.06\left(\mathrm{~d}, 2 \mathrm{H}, J_{\mathrm{H}, \mathrm{H}}=3 \mathrm{~Hz}, \mathrm{H}^{4^{\prime}}\right), 6.17\left(\mathrm{dd}, 2 \mathrm{H}, J_{\mathrm{H}, \mathrm{H}}=3 \mathrm{~Hz}, J_{\mathrm{P}, \mathrm{H}}=\right.$ $\left.1 \mathrm{~Hz}, \mathrm{H}^{3}\right), 6.08\left(\mathrm{dd}, 2 \mathrm{H}, J_{\mathrm{H}, \mathrm{H}}=3 \mathrm{~Hz}, J_{\mathrm{P}, \mathrm{H}}=1 \mathrm{~Hz}, \mathrm{H}^{3}\right), 2.57$ (m, $\left.4 \mathrm{H}, 2 \mathrm{CH}_{2} \mathrm{P}_{\text {int }}\right), 2.37$ (s, 6H, $\left.\mathrm{CH}_{3}\right), 2.30\left(\mathrm{~s}, 6 \mathrm{H}, \mathrm{CH}_{3}\right), 2.18$ $\left(\mathrm{m}, 4 \mathrm{H}, \mathrm{CH}_{2} \mathrm{P}_{\text {ext }}\right) .{ }^{13} \mathrm{C}\left\{{ }^{1} \mathrm{H}\right\} \mathrm{NMR} \delta\left(\mathrm{CDCl}_{3}\right)=161.22(\mathrm{t}, 2 \mathrm{C}$, $\left.{ }^{4} J_{\mathrm{P}, \mathrm{C}}=2 \mathrm{~Hz}, \mathrm{C}^{5}\right), 160.61\left(\mathrm{t}, 2 \mathrm{C},{ }^{4} J_{\mathrm{P}, \mathrm{C}}=2 \mathrm{~Hz}, \mathrm{C}^{5}\right)$, 134.64$125.98\left(\mathrm{~m}, 14 \mathrm{C}, \mathrm{C}^{2}, \mathrm{C}^{3}\right.$ plus $\left.\mathrm{C}_{\mathrm{Ph}}\right), 109.07\left(\mathrm{t}, 4 \mathrm{C}, J_{\mathrm{P}, \mathrm{C}}=4 \mathrm{~Hz}\right.$, $\left.\mathrm{C}^{4}\right), 108.66\left(\mathrm{t}, 4 \mathrm{C}, J_{\mathrm{P}, \mathrm{C}}=4 \mathrm{~Hz}, \mathrm{C}^{4^{\prime}}\right), 29.63(\mathrm{~s}, \mathrm{br}, 2 \mathrm{C}$, $\mathrm{CH}_{2} \mathrm{P}_{\text {ext }}$ ), 26.73 (s, br, 2C, $\left.\mathrm{CH}_{2} \mathrm{P}_{\text {int }}\right), 14.22\left(\mathrm{~s}, 2 \mathrm{C}, \mathrm{CH}_{3}\right)$, $14.10\left(\mathrm{~s}, 2 \mathrm{C}, \mathrm{CH}_{3}\right) .{ }^{31} \mathrm{P}\left\{{ }^{1} \mathrm{H}\right\} \mathrm{NMR} \delta\left(\mathrm{CDCl}_{3}\right)=115.06(\mathrm{t}, 1 \mathrm{P}$, $\left.{ }^{3} J_{\mathrm{P}, \mathrm{P}}=12 \mathrm{~Hz}, \mathrm{P}_{\text {int }}\right), 9.22\left(\mathrm{~d}, 2 \mathrm{P},{ }^{3} J_{\mathrm{P}, \mathrm{P}}=12 \mathrm{~Hz}, \mathrm{P}_{\mathrm{ext}}\right)$. ESI-MS $\left(\mathrm{CH}_{2} \mathrm{Cl}_{2}\right) \mathrm{C}_{30} \mathrm{H}_{33} \mathrm{Cl}_{2} \mathrm{O}_{4} \mathrm{P}_{3} \mathrm{Pd}(727.19)$ found: $\mathrm{m} / \mathrm{z}=693.032$ [M-Cl] ${ }^{+}$, simulated: 693.031. Anal. Calc: C, 49.50; H, 4.53. Found: C, 49.14; H, 4.56.

\section{Synthesis of Complex 9}

To a mixture of $\mathrm{PdCl}_{2}(\mathrm{NCPh})_{2}(0.101 \mathrm{~g}, 264 \mathrm{mmol})$ and Triphos $(0.143 \mathrm{~g}, 267 \mathrm{mmol})$ were added $6 \mathrm{ml}$ of $\mathrm{CH}_{2} \mathrm{Cl}_{2}$. After stirring overnight, addition of $50 \mathrm{~mL}$ of $\mathrm{Et}_{2} \mathrm{O}$ allowed to precipitate the intermediate $[\mathrm{PdCl}($ Triphos $)] \mathrm{Cl}$ which was filtered and dried under vacuum. $\mathrm{TlPF}_{6}(0.187 \mathrm{~g}, 0.536$ mmol), $7 \mathrm{ml}$ of $\mathrm{CH}_{2} \mathrm{Cl}_{2}$ and few drops of $\mathrm{CH}_{3} \mathrm{CN}$ were then added to this complex and the resulting suspension was stirred for 4 hours. After filtration, the solution was concentrated to the half volume under vacuum. Addition of $10 \mathrm{ml}$ of $\mathrm{Et}_{2} \mathrm{O}$ afforded the expected complex $\mathbf{6}$ as a beige powder which was dried under vacuum (139 mg, $91 \%)$. ${ }^{\mathrm{H}} \mathrm{H}$ NR $\delta$ $\left(\mathrm{CDCl}_{3}\right)=7.85-7.20\left(\mathrm{~m}, 25 \mathrm{H}, \mathrm{H}_{\text {aromatics }}\right), 3.81-2.74(\mathrm{~m}, 8 \mathrm{H}$, $\left.4 \mathrm{PCH}_{2}\right), 2.17\left(\mathrm{~s}, 3 \mathrm{H}, \mathrm{CH}_{3}\right)$. No ${ }^{13} \mathrm{C}\left\{{ }^{1} \mathrm{H}\right\} \mathrm{NMR}$ data due to the lower solubility of $\mathbf{6}$ in common polar solvents. ${ }^{31} \mathrm{P}\left\{{ }^{1} \mathrm{H}\right\}$ NMR $\delta\left(\mathrm{CDCl}_{3}\right)=110.38\left(\mathrm{t}, 1 \mathrm{P}, \mathrm{P}_{\mathrm{int}},{ }^{3} \mathrm{~J}_{\mathrm{P}, \mathrm{P}}=10.6 \mathrm{~Hz}\right), 45.70$ (d, $2 \mathrm{P}, \mathrm{P}_{\mathrm{ext}},{ }^{3} J_{\mathrm{P}, \mathrm{P}}=10.6 \mathrm{~Hz}$ ), -144.25 (hept., $1 \mathrm{P}, \mathrm{PF}_{6}^{-}, J_{\mathrm{P}, \mathrm{F}}=$ $571 \mathrm{~Hz}$ ). ESI-MS (positive mode, $\mathrm{CH}_{2} \mathrm{Cl}_{2} / \mathrm{MeOH}$ ) found for $\mathrm{C}_{36} \mathrm{H}_{36} \mathrm{NP}_{5} \mathrm{PdF}_{12}$ (971.04) $\mathrm{m} / \mathrm{z}=699.093[\mathrm{M}+\mathrm{F}-\mathrm{H}]^{2+}$, simulated: 699.101. Anal. Calc. for $\mathrm{C}_{36} \mathrm{H}_{36} \mathrm{NP}_{5} \mathrm{PdF}_{12}$ ( $\mathrm{M}=971.04)$ : $\mathrm{C}, 44.49 ; \mathrm{H}, 3.74 ; \mathrm{N}, 1.44$. Found: $\mathrm{C}, 44.95, \mathrm{H}$, $3.86, \mathrm{~N}, 1.74$.

\section{Synthesis of Complex 11}

To a mixture of complex $\mathrm{PdCl}_{2}(\mathrm{NCPh})_{2}(145 \mathrm{mg}, 0.378$ $\mathrm{mmol})$ and ligand 5 (298 $\mathrm{mg}, 0.523 \mathrm{mmol})$ were added $10 \mathrm{ml}$ of $\mathrm{CH}_{2} \mathrm{Cl}_{2}$. A red solution was obtained after few minutes. After stirring overnight, the solution was strongly concentrated under vacuum and addition of $15 \mathrm{ml}$ of $\mathrm{Et}_{2} \mathrm{O}$ afforded the intermediate complex $\mathbf{6}$ which was filtered and dried under vacuum for 3 hours. TlPF $_{6}(0.319 \mathrm{~g}, 0.913 \mathrm{mmol}), 15$ $\mathrm{ml}$ of $\mathrm{CH}_{2} \mathrm{Cl}_{2}$ and few drops of $\mathrm{CH}_{3} \mathrm{CN}$ were then added and the resulting mixture became a red suspension after 3 hours stirring. After filtration, the solvent was partially removed and a beige powder was formed by addition of $10 \mathrm{ml}$ of $\mathrm{Et}_{2} \mathrm{O}$, which was washed with $\mathrm{Et}_{2} \mathrm{O}$ and dried under vacuum (243 mg, $64 \%)$. ${ }^{1} \mathrm{H}$ NMR $\delta\left(\mathrm{CD}_{2} \mathrm{Cl}_{2}\right)=7.83-7.11(\mathrm{~m}, 20 \mathrm{H}$, $\left.\mathrm{H}_{\text {aromatics }}\right), 3.31-2.32\left(\mathrm{~m}, 16 \mathrm{H}, \mathrm{N}\left(\mathrm{CH}_{2}\right)_{3}, 5 \mathrm{PCH}_{2}\right), 1,88(\mathrm{~s}, 3$ $\left.\mathrm{H}, \mathrm{CH}_{3}\right) .{ }^{13} \mathrm{C}\left\{{ }^{1} \mathrm{H}\right\}$ NMR $\delta\left(\mathrm{CD}_{2} \mathrm{Cl}_{2}\right)=163.36(\mathrm{~s}, 1 \mathrm{C}, \mathrm{NCN})$, 133.52-128.28 (m, $\left.24 \mathrm{C}, \mathrm{C}_{\text {aromatics }}\right), 51.42$ (s, $1 \mathrm{C}$, $\left.\underline{\mathrm{CH}}_{2}(\mathrm{~N}=\mathrm{C})\right), 50.38\left(\mathrm{~s}, 1 \mathrm{C}, \underline{\mathrm{CH}}_{2}(\mathrm{~N}-\mathrm{C})\right), 41.52$ (s, br, $1 \mathrm{C}$, $\overline{\mathrm{CH}}_{2} \mathrm{~N}$ ), 29.88 (s, br, $\left.3 \mathrm{C}, \overline{\mathrm{P}}\left(\mathrm{CH}_{2}\right)_{3}\right), 27.42$ (s, br, $2 \mathrm{C}, 2$ $\left.\mathrm{CH}_{2} \mathrm{PPh}_{2}\right), 15.53\left(\mathrm{~s}, 1 \mathrm{C}, \mathrm{CH}_{3}\right) .{ }^{31} \mathrm{P}\left\{{ }^{1} \mathrm{H}\right\} \mathrm{NMR} \delta\left(\mathrm{CD}_{2} \mathrm{Cl}_{2}\right)=$ 107.94 (s, br, 1 P, $\mathrm{P}_{\text {internal }}$ ), 30.77 (s, br, 2 P, $\mathrm{P}_{\text {external }}$ ), -144.31 (hept., $1 \mathrm{P}, \mathrm{PF}_{6}, J_{\mathrm{P}, \mathrm{F}}=712 \mathrm{~Hz}$ ). Anal. Calc. for $\mathrm{C}_{36} \mathrm{H}_{42} \mathrm{~N}_{3} \mathrm{P}_{5} \mathrm{PdF}_{12}(\mathrm{M}=1005.09): \mathrm{C}, 42.98 ; \mathrm{H}, 4.21 ; \mathrm{N}, 4.18$. Found: C, 42.66, H, 4.35, N, 4.45.

\section{Synthesis of Complex 12}

To a mixture of complex $7(150 \mathrm{mg}, 0.206 \mathrm{mmol})$ and thallium hexafluorophosphate $(250 \mathrm{mg}, 0.715 \mathrm{mmol})$ were added $7 \mathrm{ml}$ of acetonitrile. The yellow suspension was stirred for 3 hours at room temperature and then filtrated over Celite $^{\circledR}$. After evaporation of solvent, a yellow viscous residue was obtained which was washed with $\mathrm{Et}_{2} \mathrm{O}$ and dried for 2 hours under vacuum $(200 \mathrm{mg}, 85 \%)$. ${ }^{1} \mathrm{H}$ NMR $\delta\left(\mathrm{CDCl}_{3}\right)=$ $8.30\left(\mathrm{~m}, 2 \mathrm{H}, \mathrm{H}_{\mathrm{Ph}}\right), 7.65\left(\mathrm{~m}, 3 \mathrm{H}, \mathrm{H}_{\mathrm{Ph}}\right), 7.48\left(\mathrm{~d}, 2 \mathrm{H}, J_{\mathrm{H}, \mathrm{H}}=3\right.$ $\left.\mathrm{Hz}, \mathrm{H}^{4}\right), 7.05\left(\mathrm{~d}, 2 \mathrm{H}, \mathrm{J}_{\mathrm{H}, \mathrm{H}}=3 \mathrm{~Hz}, \mathrm{H}^{4}\right), 6.27(\mathrm{dd}, 2 \mathrm{H}, \mathrm{JH}, \mathrm{H}=$ $\left.3 \mathrm{~Hz}, \mathrm{JP}, \mathrm{H}=1 \mathrm{~Hz}, \mathrm{H}^{3}\right), 6.21(\mathrm{dd}, 2 \mathrm{H}, \mathrm{JH}, \mathrm{H}=3 \mathrm{~Hz}, \mathrm{JP}, \mathrm{H}=1$ $\mathrm{Hz}, \mathrm{H} 3$ '), 3.25 (m, 4H, $\left.\mathrm{CH}_{2} \mathrm{P}_{\text {int }}\right), 2.43\left(\mathrm{~s}, 6 \mathrm{H}, \mathrm{CH}_{3}\right), 2.40$ (s, $\left.6 \mathrm{H}, \mathrm{CH}_{3}\right), 2.2\left(\mathrm{~m}, 4 \mathrm{H}, \mathrm{CH}_{2} \mathrm{P}_{\text {ext }}\right)$. No ${ }^{13} \mathrm{C}\left\{{ }^{1} \mathrm{H}\right\} \mathrm{NMR}$ data due to the lower solubility of $\mathbf{1 2}$ in common polar solvents. ${ }^{31} \mathrm{P}\left\{{ }^{1} \mathrm{H}\right\} \operatorname{NMR} \delta\left(\mathrm{CDCl}_{3}\right)=117.09\left(\mathrm{t}, 1 \mathrm{P},{ }^{3} J_{\mathrm{P}, \mathrm{P}}=11 \mathrm{~Hz}, \mathrm{P}_{\text {int }}\right)$, $11.25\left(\mathrm{~d}, 2 \mathrm{P},{ }^{3} J_{\mathrm{P}, \mathrm{P}}=11 \mathrm{~Hz}, \mathrm{P}_{\mathrm{ext}}\right)$. Anal. Calc for $\mathrm{C}_{32} \mathrm{H}_{36} \mathrm{NO}_{4} \mathrm{P}_{5} \mathrm{~F}_{12} \mathrm{Pd}$ (987.90): C, 38.90; H, 3.67; N, 1.42. Found: C, 38.64; H, 3.56, N, 1.67.

\section{General Procedure for Methoxylation of Alkynes in an Ionic Liquid}

Example given with complex 9: $(10.3 \mathrm{mg}, 0.011 \mathrm{mmol}$, $0.2 \mathrm{~mol} \%$ ) of 9 was dissolved in a mixture of $0.5 \mathrm{ml}$ of [BMIM] $\left(\mathrm{BF}_{4}\right)$ and $0.5 \mathrm{ml}$ of $\mathrm{CH}_{3} \mathrm{OH}(12.3 \mathrm{mmol})$. After addition of phenylacetylene $(0.5 \mathrm{ml}, 4.55 \mathrm{mmol})$, the solu- 
tion was stirred for 5 days. Organic compounds were isolated from the catalytic system, under inert atmosphere, by five successive extractions with $5 \mathrm{ml}$ of heptane. The selectivity of the reaction is total and isolated yields of products are obtained at $90 \%$ to $95 \%$ of the conversion reported. After evaporation of the solvent, the mixture of $\mathrm{PhC} \equiv \mathrm{CH}$, $\mathrm{PhC}(\mathrm{O}) \mathrm{CH}_{3}$ and $\mathrm{PhC}\left(\mathrm{OCH}_{3}\right)_{2} \mathrm{CH}_{3}$ was analyzed by proton and carbon NMR spectroscopy. Methanol $(0.5 \mathrm{ml}, 12.3$ $\mathrm{mmol})$ and phenylacetylene $(0.5 \mathrm{ml}, 4.55 \mathrm{mmol})$ were added to the recovered ionic liquid for further catalytic runs. NMR data of $\mathrm{PhC}\left(\mathrm{OCH}_{3}\right)_{2} \mathrm{CH}_{3}:{ }^{1} \mathrm{H}$ NMR $\delta\left(\mathrm{CDCl}_{3}\right)=7.43-7.18$ $\left(\mathrm{m}, 5 \mathrm{H}, \mathrm{H}_{\text {aromatics }}\right), 3.10\left(\mathrm{~s}, 6 \mathrm{H}, 2 \mathrm{OCH}_{3}\right), 1.46\left(\mathrm{~s}, 3 \mathrm{H}, \mathrm{CH}_{3}\right)$. ${ }^{13} \mathrm{C}\left\{{ }^{1} \mathrm{H}\right\}$ NMR $\delta\left(\mathrm{CDCl}_{3}\right)=143.15-122.42(6 \mathrm{~s}, 6 \mathrm{C}$, $\left.\mathrm{C}_{\text {aromatics }}\right), 101.92\left(\mathrm{~s}, 1 \mathrm{C}, \mathrm{CH}_{3} \mathrm{C}\left(\mathrm{OCH}_{3}\right)_{2}\right), 49.16(\mathrm{~s}, 2 \mathrm{C}$, $\left.\mathrm{OCH}_{3}\right), 26.35\left(\mathrm{~s}, 1 \mathrm{C}, \mathrm{CH}_{3}\right)$.

\section{Crystal Structure Determination for Compound 2a}

Crystal data and refinement details are reported in Table 2. Data sets were collected on an Enraf-Nonius Kappa CCD diffractometer at $115 \mathrm{~K}$ using $\mathrm{MoK} \alpha$ radiation. The structure was solved using Direct Methods (SIR 92) [36] and refined with full-matrix least-squares methods based on $\left|\mathrm{F}^{2}\right|$ (SHELX-97) [37] with the aid of the WINGX [38] program. All non-hydrogen atoms were refined with anisotropic thermal parameters. Hydrogen atoms were included in their calculated positions and refined as riding atoms. CCDC808224 for 2a contains the supplementary crystallographic data for this paper. These data can be obtained free of charge at www.ccdc.cam.ac.uk/conts/retrieving.html [or from the Cambridge Crystallographic Data Centre, 12, Union Road, Cambridge CB2 1EZ, UK; fax: (internat.) +44-1223/336033; E-mail: deposit@ccdc.cam.ac.uk].

\section{ABBREVIATION}

Triphos $=\quad\left[\mathrm{Ph}_{2} \mathrm{P}\left(\mathrm{CH}_{2}\right)_{2} \mathrm{PPh}\left(\mathrm{CH}_{2}\right)_{2} \mathrm{PPh}_{2}\right]$

\section{CONFLICT OF INTEREST}

None declared.

\section{REFERENCES}

[1] Tocco, G.; Begala, M.; Meli, G.; Podda, G. $\mathrm{InCl}_{3}$ and $\mathrm{ZrCl}_{4}$ catalyzed regioselective reaction of 2,2'-dihydroxybiphenyl with terminal alkynes: synthesis of new dibenzo $[d, f]$ [1,3]dioxepines. Tetrahedron, 2008, 64, 6755-6759.

[2] Santos, L.L.; Ruiz, V.R.; Sabater, M.J.; Corma, A. Regioselective transformation of alkynes into cyclic acetals and thioacetals with a gold(I) catalyst: comparison with Brønsted acid catalysts. Tetrahedron, 2008, 64, 7902-7909.

[3] Genin, E.; Antoniotti, S.; Michelet, V.; Genêt, J.-P. An Ir-catalyzed exo-selective tamdem cycloisomerization/hydroalkoxylation of bishomopropargylic alcohols at room temperature. Angew. Chem. Int. Ed. Engl., 2005, 44, 4949-4953.

[4] Dilk, E.; Acetals, leur utilisation comme matières odorantes et leur procédé de production. PCT. Int. Appl. WO2005009984 (A1), 2005.

[5] Climent, M.J.; Velty, A.; Corma, A. Design of a solid catalyst for the synthesis of a molecule with blossom orange scent. Green Chem., 2002, 4, 565-569.

[6] Climent, M.J.; Corma, A.; Velty, A.; Susarte, M. Zeolites for the production of fine chemicals: Synthesis of the fructone fragrancy. J. Catal., 2000, 196, 345-351.

[7] Francke, W.; Kitching, W. Spiroacetals in Insects. Curr. Org. Chem. 2001, 5, 233-251.
[8] Yeung, K.S.; Paterson, I. Advances in the total synthesis of biologically important marine macrolides. Chem. Rev., 2005, 105, 4237-4313.

[9] Diéguez-Vázquez, A.; Tzschucke, C.C.; Crecente-Campo, J.; McGrath, S.; Ley, S.V. $\mathrm{AuCl}_{3}$-catalyzed hydroalkoxylation of conjugated alkynoates: Synthesis of five- and six-Membered cyclic acetals. Eur. J. Org. Chem., 2009, 11, 1698-1706.

[10] Aepkers, M.; Wünsch, B. Structure-affinity relationship studies of non-competitive NMDA receptor anatagonists derived from dexoxadrol and etoxadrol. Bioinorg Med. Chem., 2005, 13, 68366849.

[11] Kaihara, S.; Matsumura, S.; Fisher, J.P. Synthesis and properties of poly[poly(ethyleneglycol)-co-cyclicacetal] based hydrogels. Macromolecules, 2007, 40, 7625-7632.

[12] Messerle, B.A.; Vuong, K.Q. Rhodium and iridium catalysed double hydroalkoxylation of alkynes, an efficient method for the synthesis of $O, O$-acetals: Catalytic and mechanistic studies. Organometallics, 2007, 26, 3031-3040.

[13] Hartman, J.W.; Sperry, L. Platinum(II)-catalyzed addition of alcohols to alkynes. Tetrahedron Lett., 2004, 45, 3787-3788.

[14] Hirabayashi, T.; Okimoto, Y.; Saito, A.; Morita, M.; Sakaguchi, S.; Ishii, Y. Iridium complex-catalyzed addition of water and alcohols to non-activated terminal alkynes. Tetrahedron, 2006, 62, 22312234.

[15] Konkol, M.; Schmidt, H.; Steinborn, D. Iridium-catalyzed addition of methanol to terminal alkynes. J. Mol. Catal. A, 2007, 269, 119124.

[16] Tèles, J.H.; Brode, S.; Chabanas, M. Cationic gold complexes: highly efficient catalysts for the addition of alcohols to alkynes. Angew. Chem. Int. Ed. Engl., 1998, 37, 1415-1418.

[17] Bates, C.G.; Saejueng, P.; Murphy, J.M.; Venkataraman, D. Synthesis of 2-Aryl-benzo[b]furans via copper(I)-catalyzed coupling of o-iodophenols and aryl acetylene. Org. lett., 2002, 4, 4727-4729.

[18] Zhao, L.; Cheng, G.; Hu, Y. A novel multicomponent reaction to synthesize substituted furo[3,2-c]chromenes via a Pd-catalyzed cascade process. Tetrahedron Lett., 2008, 49, 7364-7367.

[19] Saleh, S.; Fayad, E.; Azouri, M.; Hierso, J.-C.; Andrieu, J.; Picquet, M. Donor-stabilized phosphenium adducts as new efficient and immobilizing ligands in palladium-catalyzed alkynylation and platinum-catalyzed hydrogenation in ionic liquids. Adv. Synth. Catal., 2009, 351, 1621-1628.

[20] Kottsieper, K.W.; Stelzer, O.; Wasserscheid, P. 1-Vinylimidazole a versatile building block for the synthesis of cationic phosphines useful in ionic liquid biphasic catalysis. J. Mol. Catal. A, 2001, 175, 285-288.

[21] Scheffknecht, C.; Peringer, P. Palladium-catalysed transformation of non-activated terminal alkynes into acetals. J. Organomet. Chem., 1997, 535, 77-79.

[22] Andrieu, J.; Azouri, M. Synthesis of the first imidazolyltriphosphines containing a Triphos unit. Inorg. Chim. Acta, 2007, 360, 131-135.

[23] Andrieu, J.; Harmand, L.; Picquet, M. Firsts lysidinyl- and lysidinium-triphosphines Pd(II) complexes. Polyhedron, 2010, 29, 601605.

[24] Klement, I.; Rottländer, M.; Tucker, C.E.; Majid, T.N.; Knochel, P. Preparation of polyfunctional aryl and alkenyl zinc halides from functionalized unsaturated organolithiums and their reactivity in cross-coupling and conjugated addition reactions. Tetrahedron, 1997, 52, 7201-7220.

[25] Sakai, M.; Hayashi, H.; Miyaura, N. Rhodium-catalyzed conjugate addition of aryl- 1-alkenylboronic acids to enones. Organometallics, 1997, 16, 4229-4231.

[26] Tolmachev, A.A.; Ivonin, S.P.; Pinchuk, A.M. Phosphorylation of five-membered aromatic heterocycles with phosphorus tribromide. Heteroatom Chem., 1995, 6, 407-411.

[27] Hierso, J.C.; Fihri, A.; Amardeil, R.; Meunier, P.; Doucet, H.; Santelli, M. Use of a bulky phosphine of weak $\sigma$-donicity with palladium as a versatile and highly-active catalytic system: allylation and arylation coupling reactions at $10^{-1}-10^{-4} \mathrm{~mol} \%$ catalyst loadings of ferrocenyl bis(difurylphosphine)/Pd. Tetrahedron, 2005, 61, 9759-9766.

[28] Rabinowitz, R.; Pellon, J. Phosphorus-Containing Monomers. I. The synthesis of vinyl phosphines, oxides, sulfides, and phosphonium compounds. J. Org. Chem., 1961, 26, 4623-4626.

[29] Ackermann, M.; Pascariu, A.; Höcher, T.; Ullrich Siehl, H.U.; Berger S. Electronic properties of furyl substituents at phosphorus 
and their influence on ${ }^{31} \mathrm{P}$ NMR chemical shifts. J. Am. Chem. Soc., 2006, 128, 8434-8440.

[30] Fernández, D.; Sevillano, P.; García-Seijo, M.I.; Castiñeiras, A.; Jánosi, L.; Berente, Z.; Kollár, L.; García-Fernández, M.E. Influence on reactivity of chloro ligand substitution in mononuclear cationic $\mathrm{Pd}(\mathrm{II})$ and $\mathrm{Pt}(\mathrm{II})$ triphos complexes: X-ray structure of the nitrate derivatives. Inorg. Chim. Acta, 2001, 312, 40-52.

[31] DuBois, D. L.; Miedaner, A. Mediated electrochemical reduction of $\mathrm{CO}_{2}$. Preparation and comparison of an isoelectronic series of complexes. J. Am. Chem Soc., 1987, 109, 113-117.

[32] Camacho, D.H.; Shinichi, S.; Yamamoto, Y. Anti-Wacker'-type hydroalkoxylation of diynes catalyzed by palladium(0). Tetrahedron Lett., 2002, 43, 1085-1088.

[33] Collman, J.P.; Hegedus, L.S.; Norton, J.R.; Finke, R.G. Principles and applications of organotransition metal chemistry; University Science Books: Mill Valley, CA, 1987.
[34] Suarez, P.A.Z.; Dullius, J.E.L.; Einloft, S.; De Souza, R.; Dupont, $\mathrm{J}$. The use of new ionic liquids in two-phase catalytic hydrogenation reaction by rhodium complexes. Polyhedron, 1996, 15, 12171219.

[35] Fernández, D.; García-Seijo, M.I.; Sevillano, P.; Castiñeiras, A. García-Fernández, M.E. Influence of the phosphine arrangement on the reactivity of palladium(II) and platinum(II) polyphosphine complexes with copper(I) chloride. Inorg. Chim. Acta, 2005, 358, 2575-2584.

[36] Altomare A.; Cascarano G.; Giacovazzo C.; Guagliardi A. Completion and refinement of crystal structures with SIR92. J. Appl. Cryst., 1993, 26, 343-350.

[37] Sheldrick, G.M.; SHELX97 (Includes SHELXS-97 and SHELXL97), Release 97-2, Programs for Crystal Structure Analysis. University of Göttingen: Göttingen, Germany, 1998.

[38] Farrugia, L.J.; WinGX Suite for Single Crystal Small Molecule Crystallography. J. Appl. Crystallogr., 1999, 32, 837-838.

(C) Harmand et al.; Licensee Bentham Open.

This is an open access article licensed under the terms of the Creative Commons Attribution Non-Commercial License (http://creativecommons.org/licenses/ by-nc/3.0/) which permits unrestricted, non-commercial use, distribution and reproduction in any medium, provided the work is properly cited. 